\title{
Workplace Health and Safety in the Informal Sector: A Case Study of Nigeria Informal Entrepreneurs
}

\author{
Funmilayo Afolabi \\ University of Amsterdam, Netherland
}

\begin{abstract}
Over half of the labour force in developing countries is employed in the small scale enterprises in the informal sector of the economy. In these enterprises, health and safety hazards are high, but existing occupational health and safety (OHS) policies and services are poorly implemented. This puts many business owners in developing countries at undue risk of fatal or non-fatal work-related health problems and associated medical costs and economic hardship. This paper examines the OHS challenges of entrepreneurs in the informal sector. The objective is to identify the OHS challenges and the stakeholders that could bring improvement. The paper reviews existing published and grey literatures gathered through desk search of electronic databases. All studies providing outcome data on OHS among informal workers were assessed for the rigor of each study. It identifies various challenges to OHS such as ignorance of occupational hazards; lack of OHS regulation in informal sector; ignorance of OHS issues and National Health Insurance Scheme (NHIS) coverage to informal sector. Suggestions made to overcome these challenges include commitment on the part of government, harnessing the activities of various stakeholders that were identified in controlling occupational hazards, and functional trade union that will provide OHS support to members. The study concludes by suggesting more empirical research on the subject matter.
\end{abstract}

Keywords: Informal sector, Nigeria, occupational health and safety. 


\section{Introduction}

There is a burgeoning interest of researchers in occupational health and safety issues among workers in the informal sector. This interest is partly due to the significant role that the informal economy plays in building the nation's economy and also the fact that informal workers have problems and constraints to decent work especially in developing countries $\mathbf{1}$. The incidence of occupational diseases and injuries associated with industrialization has declined significantly in developed countries following developments in science and technology that has led to provision of protective equipment, safer machinery and processes, and engineering controls ${ }^{2}$. However, this is not the case in developing countries and it calls for an urgent need to consider the issue of occupational health and safety in the informal sector in the developing countries, The informal sector entrepreneurs are particularly at high risk of occupational injuries and illnesses because they lack security in employment status and they are exposed to poor working conditions which increase their vulnerability $\mathbf{3 , 4}$. Moreover, these workers have inadequate access to affordable and proper health care services for themselves and their family members, thereby contributing to already precarious situation 5 .

There are various definitions put forward by different scholars on the definitions and concept of the informal sector. Some of the concepts used to describe informal economy include invisibility, backyard, underground, unorganised, irregular, black, subterranean, clandestine, illegal, unreported, shadow, unobserved, and hidden enterprises ${ }^{\mathbf{6}, 7}$. However, the definition given by NBS (2010:51) will be adopted for this study. Informal sector is decribed as the one "which operates without binding regulations (but it may or may not regulate itself internally) as well as one that operates under official regulations that do not compel rendition of official returns on its operation or process" ${ }^{\prime \mathbf{8}}$. Also, entrepreneur refers to somebody who is actively involved in starting a business or is the owner/manager of a business 9 . Therefore the working definition be adopted in this paper for informal entreprenuers is "those starting a business or are the owner/manager of a business who engage in monetary transactions not declared to the state for tax, benefit and/or labour law purposes but which are legal in all other respects". This is a slight departure from Williams' definition of informal entrepreneur that says "those starting a business or are the owner/manager of a business who engage in monetary 
transactions not declared to the state for tax, benefit and/or labour law purposes when they should be declared, but which are legal in all other respects"9. The phrase "when they should be declared" is excluded from the definition because in Nigeria context there is no binding regulation that compels rendition of official returns on the informal entrepreneurs economic activities and because the operators are largely invisible ${ }^{\mathbf{1 0}}$. Especially as it relates to the cottage and small scale business owners which are the focus of this paper. In essence, the term 'informal sector entrepreneur' in this paper refers to the self employed in their own informal sector, own-account workers, artisans, petty traders, and all those who start up their own businesses. The reasoning for this is that they are the ones that can effect issue of OHS at their workplace.

Based on this context, this paper identifies the various challenges in occupational health and safety in the Nigeria's informal sector. The rationale for this focus is the fact that Nigeria is one of the countries that signed the 1981 Geneva's convention on OHS law ${ }^{5}$ and it will be interesting to see the effect on OHS management in the informal sector. Moreover, Nigeria is the most populous country in Africa and occupies a strategic position, having largest economy with a GDP of approximately $\$ 510$ billion $^{11}$ and a population close to 200 million 12. In addition, though up to date OHS databanks are not available in Nigeria, ILO reported that 238 fatalities were formally recorded between 2014 and 2016; while 3,461 occupational accidents and injuries with 137 disablements were recorded for the same period ${ }^{\mathbf{1 3}}$. These figures represent incidents in formal sector without taking numerous informal entrepreneurs who own their businesses into account. These entrepreneurs however formed the backbone of Nigerian economy contributing about $65 \%$ of the country's GDP in $2017^{\mathbf{1 4}}$. Moreover, it is estimated that over $90 \%$ of the nation's workers are employed in the informal economy ${ }^{\mathbf{1 5}}$. This paper thus seeks to answer the question "what are the OHS challenges in the informal sector?" and goes on to proffer possible solution to the identified challenges, identifying the key stakeholders that can be involved in addressing the issue of OHS in the informal sector of the country. This is with a view to promoting OHS among the informal entrepreneurs.

The paper is structured into five major parts. The first section is the introduction. The second section presents OHS in Nigeria; while section 3 examines the OHS issues in the informal 


\section{International Conference on Applied Research in BUSINESS, MANAGEMENT and ECONOMICS}

12-14 December, 2019

Barcelona, Spain

sector. Proffering possible solutions to those OHS issues is the focus of the fourth section while section five is for the discussion and conclusion.

\section{Methodology}

In this review, the author used a broad perspective approach in gathering the relevant literature $^{\mathbf{1 6}}$. The search began with International database resulting in 1,350 reference list out of which 850 came from Science direct, PubMed, Web of Science, MeSH and Medline. The key words for the search are OHS on one hand, Informal sector, and developing countries on the other hand. Synonyms of these words were also used in the search like workplace health and safety, accidents at workplace, risk management, occupational hazards, small, and medium enterprise. Relevant literatures that were included in this review were limited to the publications in the English Language only and the publications before 1995 were excluded from the review. The references were organized in two rounds. In the first round, unrelated references such as lack of focus on informal sector were excluded. The result was 266 references which were read and assessed on the originality of the empirical findings, the research design and the analysis. Fifty-six (56) references were excluded in the second round as inappropriate. In the end, 210 references were finally reviewed. Out of these references, 146 scientific articles, 22 scientific reports, 12 books or chapters in books, 6 conferences, 6 doctoral theses, and 18 others. Fifty-eight (58\%) percent of the references were published 2010-19, 21\% in 2006-2009, and the rest 1995-2005. Only a limited number of the references are included in this paper due to space factor.

The quality of the references was assessed by considering the originality of empirical findings, contribution to knowledge and whether the reference took OHS issues into consideration. This assessment resulted in understanding the present OHS practices in informal sector and what could be done to improve OHS of this sector in developing countries especially, in Nigeria. 
Fig.1: Study selection flow

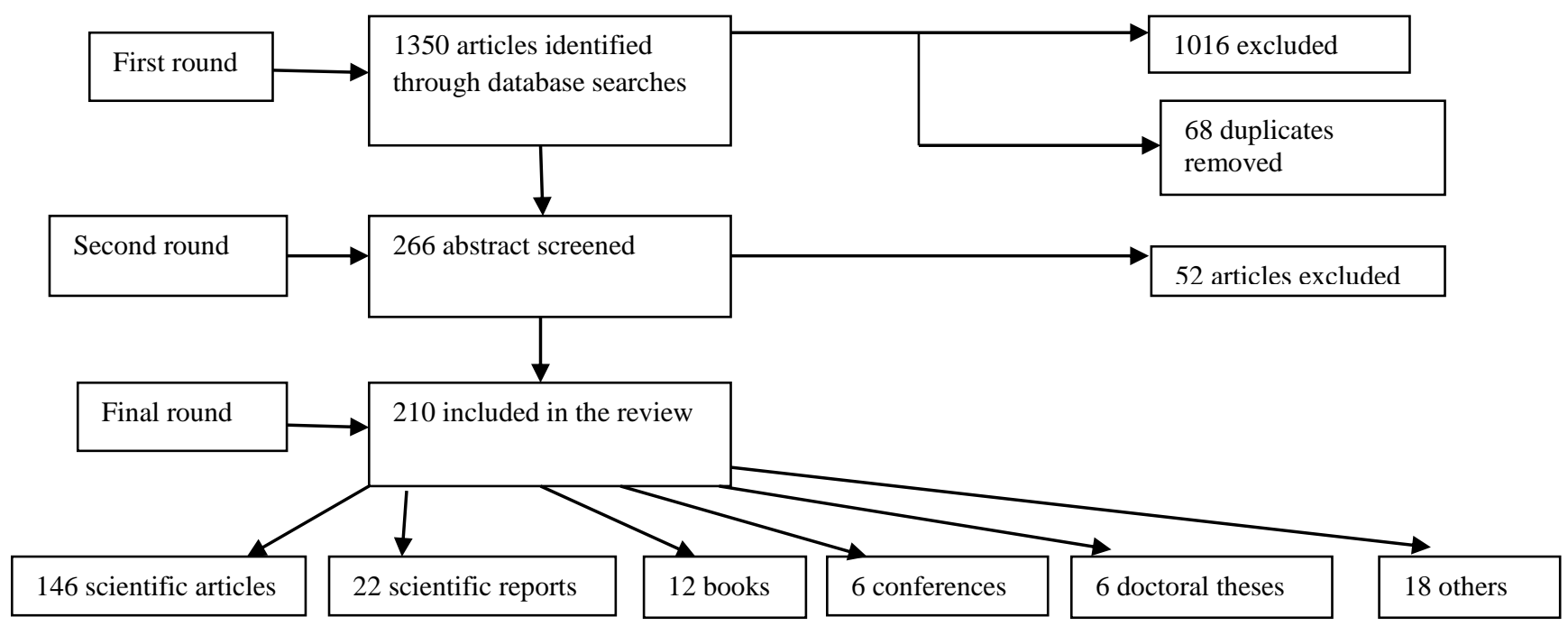




\section{Occupational Health and Safety}

\section{OHS issues}

Worldwide, extensive changes in the structure of labour market had been linked with globalisation ${ }^{17}$. In most of the less industrialised and developing countries, there has been considerable decline of jobs with work-related social benefits and secured lasting contracts. There is also increase in precarious and unprotected work. These factors contribute immensely to occupational injuries and illnesses of many workers coupled with failed hope of transition from poverty to wealth ${ }^{17}$. Occupational health risks have also been identified as one of the factors contributing to the global burden of diseases ${ }^{\mathbf{1 8}}$. ILO estimated that there are annual records of 340 million occupational accidents and 160 million victims of work-related illnesses worldwide ${ }^{\mathbf{1 9}}$. Moreover, occupational disease has continued to be the leading cause of work-related deaths ${ }^{20}$. This figure clearly negates the goal of decent work even though it only reflects the injuries and illnesses that occur in formal, registered workplace. Majority of the global burden of diseases and injuries are from Sub-Sahara Africa which has $11 \%$ of the world population, and where $80 \%$ of the population work in informal sector with no record of work-related injuries or illnesses ${ }^{3,17}$. Unfortunately, due to competing political, economic and social challenges in developing countries, occupational health issues remain largely neglected ${ }^{21}$.

\section{OHS and economic burden}

The economic cost of work-related ill health and accidents are often underestimated mainly because some costs may be difficult to quantify due to the fact that there may be greater reliance on home care which is delivered by family members on an unpaid basis ${ }^{\mathbf{2 2 , 2 3}}$. The general practice is to extrapolate epidemiological outcome from developed countries to the rest of the world. For example, the attributable fraction of diseases derived from studies in a small number of higher-income countries (especially Finland) is basically applied to the rest of the world ${ }^{24,25}$. Despite all these challenges, attempts have been made by few scholars $22,26,27$ to compute some direct and indirect costs of occupational accidents and illnesses. All these efforts are commendable but it is far from accurate because of less available data on incidence and costs of occupational injuries and illnesses in developing countries compared to developed countries $^{\mathbf{2 3}}$. Furthermore, ILO pointed out that on a national scale in developed countries, 


\section{International Conference on Applied Research in BUSINESS, MANAGEMENT and ECONOMICS}

12-14 December, 2019

Barcelona, Spain

work-related accidents and illnesses can cost up to three to four per cent of a country's gross national product ${ }^{19}$. For instance, the total cost of annual work-related ill-health and injuries in EU has been estimated to be between $€ 185$ billion and $€ 270$ billion. This is about 2.6 percent and 3.8 percent of the EU's GNP ${ }^{28}$.

\section{OHS and developing countries}

Another major issue is lack of adequate attention to health and safety in developing countries among researchers and government. This could be due to the fact that OHS practices especially in the informal sector are not considered as an important factor that can contribute to national development ${ }^{29}$. United Nations anticipated that Africa will not be able to meet most of Millennium Development Goals (MDGs) especially, those that related to health and safety, because they often ignore the importance of OHS in achieving the MDGs ${ }^{\mathbf{3 0}}$. Some of OHS issues in developing countries include lack of OHS infrastructure, training and promotion, ignorance of OHS, lack of adequate OHS education, OHS clinical and laboratory services and OHS policy formulation and implementation ${ }^{29}$.

\section{OHS and informal workers}

Many of the informal workers could not make distinction between health at home and health at work and this affects health and safety in developing countries ${ }^{17}$. The interaction between occupational hazards and poor living conditions can exacerbate the health problems of workers in the informal sector ${ }^{31}$. A good example is auto mechanic workshops. The nature of auto mechanic work lends itself to creating asbestos dust which also put family members at risk because the mechanics would come home with the asbestos dust on their clothes, shoes, and hair ${ }^{32}$. Moreover, the informal workers are ignorant of their rights to decent workplace which makes the implementation of effective OHS management difficult in developing countries ${ }^{33}$.

\section{OHS Situation analysis for Nigeria}

In 2015, the decent work deficit identified by ILO in Nigeria includes deficits in Social Protection which is due to limited social security system that caters for the need of formal workers only and ineffective National Health Insurance Scheme (NHIS). Social Dialogue Deficits caused by lack of funding by the government and lack of regular meetings among the 


\section{International Conference on Applied Research in BUSINESS, MANAGEMENT and ECONOMICS}

12-14 December, 2019

Barcelona, Spain

ILO tripartite membership. The tripartite membership comprises of the Federal Ministry of Labour and Productivity, employers' and worker's organizations in Nigeria. Hence, the National Labour Advisory Council (NLAC) has not been able to fulfil its role as an advisory body to the government on labour issues ${ }^{34}$. The Nigerian government responded to these decent work deficits and development challenges through several of her policies which include the National Economic Empowerment and Development Strategy (NEEDS) in 2004, and the national workplace policy on HIV/AIDS and its implementation guideline. However, some of these policies did not achieve much of the targets because of lack of terms of reference for the stakeholders.

Critical examination of the decent work deficits reveals direct link to formal employment and little relevance to the informal employment where majority of the workers are employed. The fact that there is no record of occupational injuries and accidents especially in the informal sector may be responsible for the lack of attention on informal workers ${ }^{\mathbf{5 , 3 5 - 3 8}}$. It is worthy to note that workers and economic units in informal economy experience specific disadvantages and most severe decent work deficits and their working conditions are precarious and unhealthy ${ }^{39}$.

Other factors identified by researchers as responsible for decent work deficits in Nigeria include lack of political will to translate scientific findings into useful policies by government $^{21}$. While the evidence of occupational hazards abounds in developing countries especially Nigeria, the policy makers prefer addressing what they considered as "more serious" social and health issues that are politically less complicated and which are more saleable to the general public. Hence the circle of neglects grows from low priority to limited allocation of resources; to inadequate research which leads to poor evidence about the significance of OHS and further leading to limited allies and partners till we reach the full circle of low priority. Figure 1 depicts cycle of neglect that occupational health in developing countries is experiencing. 
Figure 1: The occupational health 'circle of neglect' in Developing Countries

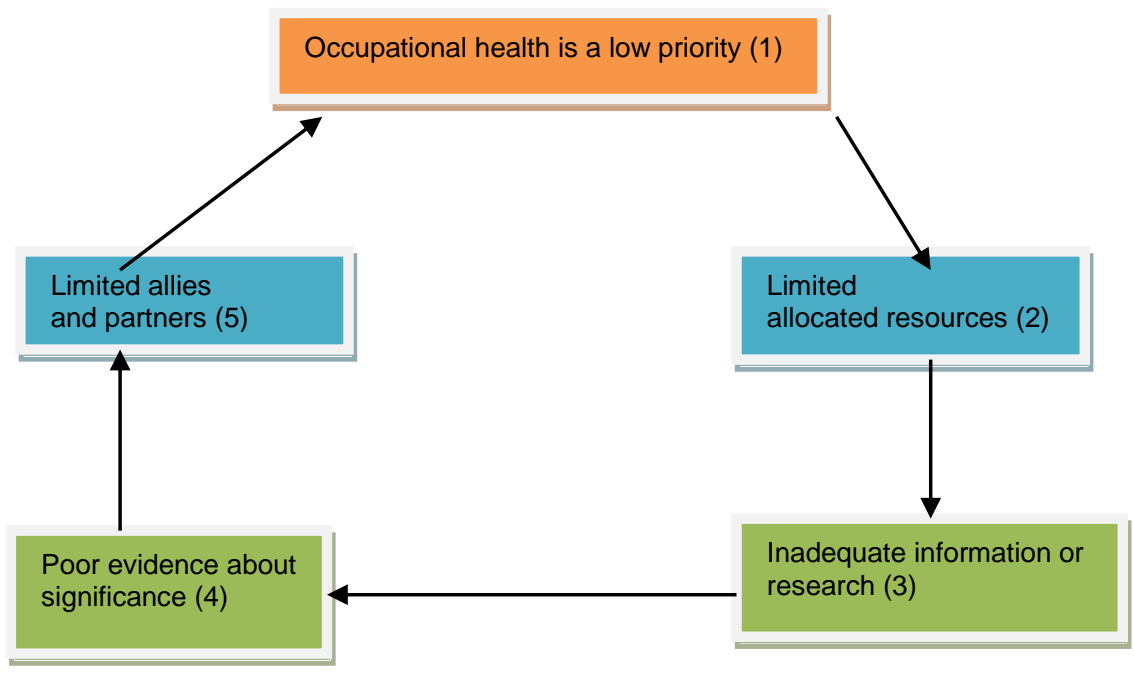

Source: Nuwayhid, 2004

\section{Occupational hazards among Nigerian informal sector entrepreneurs}

Studies among various categories of informal workers in Nigeria confirm the prevalence of occupational diseases among these workers. Johnson and Bassey ${ }^{\mathbf{4 0}}$ found prevalence of hand dermatitis among the auto technicians while Adeoye et al. ${ }^{\mathbf{1 1}}$ observed respiratory symptoms like cough, phlegm production, sneezing, dermatitis, and conjunctivitis among the saw millers. Similarly, high blood lead levels and abnormal discolouration of mucosa of the mouth was observed among the automobile technicians in Lagos, Nigeria ${ }^{\mathbf{4 2}}$. High accident rates and harassment from public authority officers were found among the street traders ${ }^{\mathbf{4 3}}$. Other hazards include exposure to extreme weathers (heat and cold), psychological stress when working under pressure etc. The lists are endless ${ }^{44-45}$. Several factors have been found to be responsible for these health problems which include exposure to lead ${ }^{46}$; manual lifting of automobile components parts, and awkward postures commonly adopted at work ${ }^{47}$; non compliance and non-usage of personal protective equipment ${ }^{\mathbf{4 8}}$; working for long hours $(>8 \mathrm{hrs})^{\mathbf{4 2}}$; inadequate work space with no proper safety equipment ${ }^{\mathbf{4 1 , 4 9}}$; and sucking petrol with mouth ${ }^{\mathbf{4 0}}$. 


\section{International Conference on Applied Research in BUSINESS, MANAGEMENT and ECONOMICS}

12-14 December, 2019

Barcelona, Spain

From the foregoing, it is evident that the informal workers earn their livelihood under dangerous and insecure conditions because jobs created under this sector often failed to meet the criteria of decent work. One may argue that the decent work deficit in the informal sector mirrors the state of OHS in Nigeria which some scholars refer to as poor because of under reporting of occupational accidents and illnesses. It also lacks regulation and enforcement ${ }^{\mathbf{5}, 35-}$ 38. Moreover, the sector has not been accorded necessary attention by government and safety professionals especially on OHS issues.

Other relevant factors responsible for poor OHS among the informal sector entrepreneurs are lack of occupational health facilities and inadequacy of health care practitioners who are trained to recognise work-related disease ${ }^{50}$. The problem of diagnosing occupational diseases and illnesses is exacerbated by a limited number of occupational health practitioners $^{51,52}$. Omokhiodon ${ }^{\mathbf{5 2}}$ reported that Nigeria has thirty (30) occupational physicians and they are mostly engaged in multinational and large national establishments and medical schools. Entrepreneurs in the informal sector have little or no access to occupational health services. Chemist shops, dispensaries, private general practice clinics, spiritual homes, and traditional herbal healers and hawkers are the major source of health care for their general health problem ${ }^{\mathbf{5 3}}$. In addition, the level of awareness of NHIS among entrepreneurs in the informal sector is very low and this prevents them from benefiting from the programme ${ }^{\mathbf{5 4}}$.

Furthermore, the activities of occupational health and safety professionals are based on the formal sector ${ }^{\mathbf{5 2}}$. There are several OHS-related organizations, some of them are the Society of Occupational Health Physicians of Nigeria (SOHPON) (but only nationally); the barely existing society of occupational health nurses; and an association of occupational safety personnel (rather non-professional in its membership, with an activity-based orientation). Their activities are fragmented and their focus is on formal sector neglecting the informal sector entrepreneurs.

It can be further argued that ignorance of informal sector entrepreneurs on issue of health and safety like the causes of occupational diseases and the cost implications of occupational accidents and diseases can also be responsible for the poor OHS management among these workers. There is also the problem of the absence of information channels and appropriate actions to reach the majority of players in the informal sector thereby leaving out a large share of the working population from vital OHS information and services ${ }^{\mathbf{5 5}}$.

In summary, the OHS challenges among Nigeria informal sector entrepreneurs include the followings; 
1. Inactivity of NLAC and lack of clarity of terms of reference for stakeholders in the policies ${ }^{34}$

2. Lack of regulation and enforcement ${ }^{5}$

3. Under reporting of occupational accidents and illnesses ${ }^{33}$

4. Poor fund allocation for $\mathrm{OHS}^{21}$.

5. Lack of occupational health services and inadequacy of occupational health physicians ${ }^{\mathbf{5 0 - 5 2}}$

6. Ignorance of NHIS coverage to informal workers ${ }^{54}$

7. Ignorance of OHS issue among the workers, ${ }^{6,41}$

\section{Framework for controlling occupational hazards}

Suggested framework for controlling occupational hazards in informal sector in Nigeria from the review

\begin{tabular}{|l|l|c|}
\hline \multicolumn{1}{|c|}{ Identified problems } & \multicolumn{1}{|c|}{ Key suggestions } & Identified Stakeholders \\
\hline $\begin{array}{l}\text { Inactivity of NLAC and lack of clarity of terms of } \\
\text { reference for stakeholders in the policies. }\end{array}$ & $\begin{array}{l}\text { Sufficient funds for NLAC } \\
\text { Clarity of stakeholders terms of reference }\end{array}$ & Government \\
\hline Lack of regulation and enforcement & $\begin{array}{l}\text { Effective regulation and enforcement of OHS } \\
\text { laws }\end{array}$ & $\begin{array}{l}\text { Government } \\
\text { Trade Unions }\end{array}$ \\
\hline Under reporting of occupational accidents and illnesses & Effective reporting mechanism & \multicolumn{1}{c|}{ Government } \\
\hline Poor fund allocation for OHS & Specific budget for OHS issues & $\begin{array}{l}\text { Government } \\
\text { and inadequacy of Occupational health physicians }\end{array}$ \\
\hline $\begin{array}{l}\text { More occupational health physicians } \\
\text { Ignorance of NHIS coverage to informal workers }\end{array}$ & $\begin{array}{l}\text { Enlightenment programme for informal workers } \\
\text { on NHIS coverage }\end{array}$ & $\begin{array}{l}\text { Government } \\
\text { Entrepreneurship } \\
\text { institutions }\end{array}$ \\
\hline Ignorance of OHS issues among the informal workers & $\begin{array}{l}\text { Constructive training on OHS for informal } \\
\text { workers } \\
\text { Attitudinal change towards OHS }\end{array}$ & $\begin{array}{l}\text { Entrepreneurship institutions } \\
\text { Research Institution } \\
\text { OHS Professionals } \\
\text { Workers }\end{array}$ \\
\hline
\end{tabular}

\section{Discussion and Conclusion}

Inactivity of NLAC and lack of clarity of terms of reference for stakeholders in the policy

Government has the responsibility of making clear the role of each actor in the governing council and provide enough funds to run it. These might ensure regular meeting of NLAC, where OHS will be discussed. Furthermore, informal worker's representatives should be part of the tripartite mechanism. There is need for inclusive representative of all workers because 


\section{International Conference on Applied Research in BUSINESS, MANAGEMENT and ECONOMICS}

12-14 December, 2019

Barcelona, Spain

the existing worker's representative are composed of formal workers. This has been achieved in Ghana, Benin, and Colombia ${ }^{1}$, so it could be done in Nigeria too.

\section{Lack of regulation and enforcement}

The government should provide a framework on which OHS will be based in Nigeria. For instance, the government should provide mandatory guidelines for people going into business to follow. This will apply to all categories of workers in the informal economy; whether they are starting a business in front of their homes, on the street or renting a shop. There is need for government to adopt the resolutions of ILO on OHS and adapt it into Nigerian situation, especially, the two areas for action that ILO is focussing on. The first action deals with developing a preventive safety and health culture while the second is to develop a system approach to manage OHS. Government must also be ready to uphold the three core values of ILO that states (1) 'work should take place in a safe and healthy working environment'; (2) 'conditions of work should be consistent with worker's well-being and human dignity' and (3) 'work should offer real possibilities for personal achievement, self-fulfilment and service for society'. Political leaders must be ready to give what it takes to see to the healthy work place in the informal sector by making sure that the enforcement agents are functional.

\section{Under reporting of occupational accidents and illnesses}

The government must ensure that workplace accidents, injuries, and diseases are reported. The national information management system for occupational injuries, accidents and diseases that was proposed in the 2012 bill should be made functional. It should not be in paper alone; this will provide the much-needed database of occupational injuries, accidents and diseases that will help in the provision of actual burden of diseases globally.

The trade unions and associations have a part to play in this regard. It can be structured in a way that it will be an avenue for reporting occupational injuries, accidents and diseases for workers. Anecdotal evidence shows that in Nigeria, most of the informal sector has trade unions and associations. Examples are market women association, national union of road and transport workers (NURTW), various artisanal unions to mention a few. In view of the relevance of association, government should encourage all workers in economic activities 


\section{International Conference on Applied Research in BUSINESS, MANAGEMENT and ECONOMICS}

12-14 December, 2019

Barcelona, Spain

that are yet to have association to do so. Moreover, the ones in existence should be strengthened and encourage to be involved in OHS issues as it affects their members. Government should provide enabling environment for these association to function.

\section{Poor fund allocation for OHS}

Another important way forward is for government to have a special vote for occupational health and safety. A sizeable portion of annual budget should be allocated to OHS especially and the disbursement should be monitored.

Lack of occupational health services and inadequacy of occupational health physicians The government should provide occupational health services for the workers in the informal sector. The occupational health services should be able to provide appropriate health care for specific health risks of the enterprise. This can be done through primary health care delivery in the country. That means the health centres must be equipped with drugs and medical personnel to be able to provide these services. Moreover, public health practitioners should be encouraged to have interest in OHS. This will help a lot in advising the workers on how to avoid work-related illnesses.

\section{Ignorance of NHIS coverage to informal workers}

The government needs to create awareness on the rights of informal workers to NHIS coverage and to what extent they can benefit from it. The awareness can be done through the use of posters and media houses such as radio and television. Also, enlightenment programmes can be done through the various association meetings by OHS practitioners and entrepreneurship institutions.

\section{Ignorance of OHS issues among the workers}

Several stakeholders involvement in designing constructive training programmes (using different institutional mechanisms) will be helpful. For instance, entrepreneurship institutions across the country can include practical strategies to improve safety at the workplace for informal workers in their curriculum. Also, the benefits of incorporating OHS in business start up will be beneficial. Moreover, research focusing on the OHS will be helpful in that it will highlight different aspects of work that are hazardous and the cost effects of such hazardous activities on the entrepreneur. The OHS professionals are other stakeholder in this regard. All the OHS professional bodies in Nigeria have one major focus of improving the 


\section{International Conference on Applied Research in BUSINESS, MANAGEMENT and ECONOMICS}

12-14 December, 2019

Barcelona, Spain

working condition of workers. In order to consolidate the efforts of these OHS professionals, there is need to harmonise their activities to address OHS issues in Nigeria. Moreover, the focus of these professional are on the formal sector so there is need for them to include the informal sector in their activities. They should have enlightenment programmes for the entrepreneurs in the informal sector. Also workable mechanism should be put in place to develop a partnership with a larger range of governmental institutions, non-governmental institutions, and community-based facilities.

Trade unionism and business associations are powerful tools that can be used in educating the informal workers about occupational diseases and cost implication of occupational hazards. These trade unions can serve as a regulatory body on OHS issues in addition to what they have been doing. The unions and associations can ensure that workers provide and maintain proper hygiene and sanitary conveniences at workplace.

The informal workers themselves have an important role to play in controlling workplace accidents and injuries. They must be willing to have a change of attitude towards their safety. They must realize the association between good health and productivity and the effect that exposure to occupational hazards can have on their health later in life. If other parameters are put in place and the workers themselves are not ready to change their attitude about safety, all the efforts will not produce any positive result. Moreover, the workers must be encouraged to join an association that is relevant to their economic activities. This will increase their chance to negotiate, lobby, and influence government policy in favour of their association.

Moreover, these workers must be ready to invest in OHS, for instance by buying personal protective equipment that can protect them from accident and illness; also by putting safety mechanics in place in their work environment. These will help in eliminating occupational hazards in the informal sector. They must also be willing to report all injuries, accidents and diseases to their respective unions. This will form the data base that will provide the statistics of occupational hazards among the sector in Nigeria. It will also help in providing the much needed statistics of global burden of diseases and accidents which will make it easier to assist the workers.

In a workplace where there is master craft person and apprentices, informal apprenticeship is the main source of skill training. It is important at this learning stage that the masters explain 


\section{International Conference on Applied Research in BUSINESS, MANAGEMENT and ECONOMICS}

the hazards inherent in the trade to the apprentices. The master must also expose the apprentices to the best practice in controlling the hazards in their workplace.

\section{Conclusion}

This paper has been able to identify the challenges that informal sector entrepreneurs in Nigeria are facing with regards to OHS. It identifies ignorance of health and safety issues as factors responsible for poor attitude towards occupational health and safety among the informal sector workers. Moreover, there is no binding official regulations and enforcement of occupational and safety standard among this group. Since regulation among the formal sector is not well coordinated by government, regulating the informal sector proves to be a herculean task. Lack of occupational health facilities and access to healthcare services are other challenges identified as factors negatively influencing OHS in Nigeria.

The paper therefore identifies some key stakeholders that can be used in confronting the issue of occupational health and safety among the informal sector - the government; the informal sector entrepreneurs; public health practitioners; research institutions; the trade unions and business association; OHS professionals and entrepreneurship institutions. If the efforts of all these stakeholders could be harnessed together, it will go a long way in controlling workrelated injuries and diseases in the informal sector in Nigeria.

The paper concludes that the informal sector entrepreneurs could be a major stakeholder in addressing OHS issue in the sector since it concerns them more directly. Therefore, an empirical research that will explore the perception of the workers on risk they are exposed to will be beneficial. This is because looking through the lens of these workers might provide a bottom approach to solving OHS challenges among the group. 


\section{International Conference on Applied Research in BUSINESS, MANAGEMENT and ECONOMICS}

\section{2-14 December, 2019 \\ Barcelona, Spain}

\section{References}

1. International Labour Congress. Decent work and informal economy. Geneva: ILO; 2005, 90 ${ }^{\text {th }}$ Session, Report VI. 133 p.

2. Kim Y., Park J., and Park M. (2016). Creating a culture of prevention in occupational safety and health practice. Safety and health at work 7:89-96.

3. Rockefeller Foundation. Health Vulnerabilities of Informal workers. Rockefeller Foundation; May, 2013. 129p

4. Bryan L, Conway M, Keesmaat T, McKenna S, Richardson B. Strenghtening Sub-Sahara Africa's health systems: A practical approach [Internet]. McKinsey and Company. June, 2010 [cited 2016 January 15] Available from: http://www.mckinsey.com/industries/healthcaresystems-and-services/our-insights/strengthening-sub-saharan-africas-health-systems-apractical-approach

5. Adeogun BK., Okafor CC. Occupational Health and Safety and Environment (HSE) Trend in Nigeria. J. of Envl Sci, Management and Engineering Research 2013; 2(1): 24-29.

6. Webb JW, Bruton DG, Tihanyi L, Ireland RD. Research on entrepreneurship in the informal economy: Framing a research agenda. J. Bus. Venturing 2013;i:5:598-614.

7. Duru M. Nigeria's informal sector: opportunities for self employment and income generation. Eco and Fin Review 2012; 1:11: 35 - 41.

8. National Bureau of Statistics (2010) Households and micro enterprises (informal sector) national manpower stock and employment generation survey, Nigeria. [cited 2019 Nov 20].

9. Williams C. Informal sector entrepreneurship. A background paper for the OECD Centre for Entrepreneurship, SMEs and Local Development 2014. Available from: https://papers.ssrn.com/sol3/papers.cfm?abstract_id=2731781. Accessed 20-11-2019.

10. CISLAC publication. Expanding the tax base in the informal sector in Nigeria. Availabe at: http://maketaxfair.net/assets/policy-brief-on-informal-sector.pdf. Accessed 20-11-2019. 


\section{International Conference on Applied Research in BUSINESS, MANAGEMENT and ECONOMICS}

\section{2-14 December, 2019 \\ Barcelona, Spain}

11. Umeokafor U, Isaac D, Jones K., Umeadi B. Enforcement Of Occupational Safety And Health Regulations In Nigeria: An Exploration . Euro Sci. Journal 2014:3:93-105.

12. Nigeria Populations [internet]. Worldometers 2016 [updated 2 Jan. 2017; cited 2016 Feb 10]. Available from: www.worldometers.info/world-population/nigeria-population

13. ILO 2016. Nigeria country profile on occupational safety and health [internet]. [cited 2019

Nov 20]. Available from: https://www.ilo.org/wcmsp5/groups/public/---africa/---roaddis_ababa/---ilo-abuja/documents/publication/wcms_552748.pdf

14. Bank of industry, 2018. [internet] Cited 2019 Nov 19. Available at: https://www.boi.ng/wpcontent/uploads/2018/05/BOI-Working-Paper-Series-No2_Economic-Development$\underline{\text { through-the-Nigerian-Informal-Sector-A-BOI-perspective.pdf }}$

15. Awojobi O.N., Ayakpat J., and Adisa O.D. (2014). Rebased Nigerian gross domestic product: The role of the informal sector in the development of the Nigerian economy. Int. Journ. Of Edu and Res 2(7): 301-316.

16. Cronin P, Ryan F, Coughlan M. Undertaking a literature review: a step-by-step approach. British Journal of Nursing 2008; 17:1: 38-43.

17. Lund F, Marriot A. Occupational Health and Safety and the poorest [Internet]. USA: WIEGO. 2011 April [Cited 2016 June 21]. Available from: wiego.org/sites/wiego.org/files/publications/.../Lund_WIEGO_WP20.pdf

18. Fingerhut M, Driscoll T, Imel Nelson D, Concha-Barrientos M, Punnett L, Pruss-

Ustin A, Steenland K, Leigh J, Corvalan C. Contribution of occupational risk factors to the global burden of disease-a summary of findings. SJWEH Suppl, 2005;1, 58-61.

19. ILO, 2019. [internet] cited 2019 Nov 19. Available at:

https://www.ilo.org/moscow/areas-of-work/occupational-safety-andhealth/WCMS_249278/lang--en/index.htm

20. ILO. Safety and Health at Work. Geneva: ILO 2013. [Cited 2016 Oct 05]. Available from: http://www.ilo.org/safework/events/meetings/WCMS_204594/lang--index.htm 


\section{International Conference on Applied Research in BUSINESS, MANAGEMENT and ECONOMICS}

\section{2-14 December, 2019 \\ Barcelona, Spain}

21. Nuwayhid IA. Occupational Health Research in Developing Countries: A

Partner for Social Justice. American Journal of Public Health 2004;.94:11:1916-1921.

22. Wesson HKH, Boikhutso N, Bachani AM, Hoffman KJ, Hyder AA. The cost of injury and trauma care in low -and middle -income countries: a review of economic evidence. Health Policy and Planning 2013;29:6:795-808.

23. ILO. Estimating the Economic Costs of Occupational Injuries and Illnesses in Developing Countries: Essential Information for Decision-Makers. Geneva, Switzerland: ILO 2012 [cited 2016 March 10]. Available from: www.ilo.org/wcmsp5/groups/public/--ed.../wcms_207690.pdf.

24. Hämäläinen P, Jukka T, Kaija LS. Global Estimates of Fatal Work-Related Diseases. . Am J. of Ind Med 2007; 50: 28-41.

25. Driscoll T, Takala J, Steenland K, Corvalan C, Fingerhut M. Review of Estimates of the Global Burden of Injury and Illness Due to Occupational Exposures. Am J of Ind Med 2005a; 48:6:491-502.

26. Akintola O. Unpaid HIV/AIDS Care in Southern Africa: Forms, Context, and implications. Feminist Economics 2008; 14:4 117-147

27. Nelson DI, Nelson RY, Concha-Barrientos M, Fngerhut M. The global burden of occupational noise-induced hearing loss. Am J. of Ind Med 2005;48:6: 446-58.

28. ILO. Systematization of Occupational Hazards by Occupation. Geneva, Swizerland: ILO 2008 [Cited 2016 Dec 02]. Available from: http://www.ilocis.org/documents/chpt103e.htm.

29. Puplampu BA. Key issues on Occupational Health and Safety Practices in Ghana: A Review. Int J. of Bus and Soc. Sci. 2012;3:19:151-156.

30. United Nations. The Millennium Development Goals Report. New York: UN 2012 
[cited

2016

Nov

12].

Available

from:

www.un.org/millenniumgoals/pdf/MDG\%20Report\%202012.pdf

31. Rosenstock L, Cullen M, Fingerhut M. Occupational Health. In: Jamison Dt, Breman

JG, Measham AR, et al., editors. Disease Control Priorities in Developing Countries. $2^{\text {nd }}$ edition. New York: Oxford University Press 2006; 1440p.

32. Mesothelioma Center. Asbestos Exposure and Cancer Risk [Internet]. U.S.: Office of Public Affairs Occupational Safety and Health Administration, U.S. Department of Labor. 2009 May 1. Available at: https://www.cancer.gov/about-cancer/causesprevention/risk/substances/asbestos/asbestos-fact-sheet.

33. Kheni NA, Braimah C. Institutional and Regulatory Framework for Health and Safety Administration: STudy of the Construction Industry of Ghana. Int Refereed J. of Eng. and Sci $2014 ; 3: 2: 24-34$

34. ILO. Nigeria: Decent Work Country Programme II, 2015-2018. Addisababa: ILO 2015 [cited 2016 Dec 02]. Available at: www.ilo.org/addisababa/informationresources/.../WCMS.../index.htm.

35. Diugwu IA, Baba DL, Egila AE. Effective Regulation and Level of Awareness: An An Expose of the Nigeria's Construction Industry. Open J. of Safety Sci and Tech 2012;51:8:485-489.

36. Okolie KC, Okoye PU. Assessment of National Cultural Dimensions and Construction Health and Safety Climate in Nigeria. Sci. J. of Envl Eng. Research 2012; 6.

37. Okojie O. System for reporting occupational diseases in Nigeria. African Newsletter on occupational health and safety $2010 ; 20: 3: 51-53$.

38. Idoro G. Health and Safety Management Efforts as Correlates of Performance in the Nigerian construction industry. J. of Civil Eng. and Management 2008; 14: 4: 277-285. 


\section{International Conference on Applied Research in BUSINESS, MANAGEMENT and ECONOMICS}

12-14 December, 2019

Barcelona, Spain

39. ILO [Internet]. The informal economy: enabling transition to formalization. Geneva: ILO 27$292007 \quad$ [cited $2016 \quad$ Feb 20]. Available from http://www.ilo.org/emppolicy/events/WCMS_125489/lang--en/index.htm.

40. Johnson, O.E., and Bassey, E.A. (2016). Work habits and health problems of automobile technicians at mechanic village, Uyo, Nigeria. J. of medicine and medical science 5(5): 136-142.

41. Adeoye OA, Adeomi AA, Abodunrin OL, Olugbenga-Bello AI, Abdulsalam ST. Awareness of occupational hazards and health problems among sawmill workers in Osun Staste, Nigeria. Int. Journal of Research and Review 2015; 2:1: 1-14.

42. Saliu A, Adebayo O, Kofoworola O, Babatunde O, Ismail A. Comparative Assessment of Blood Lead levels of Automobile Technicians in Organised and Road side Garages in Lagos, Nigeria.

J. of Env and Public Health 2015:1-9.

43. Olurinola IO, Fadayomi T, Amoo EO, Ola-David O. Occupational Health and Safety among street traders in Nigeria. Int J. of Econs and Finance 2014; 6:4: 59-79.

44. ILO/CIS. International hazards datasheets on Occupation: Mechanic, automobile. Geneva: ILO, CIS, IIOSH 2012. [Cited 2016 March 12]. Available from: www.ilo.org/safework/cis/WCMS_193167/lang--en/index.htm.

45. Sambo MN, Idris SH, Shamang A. Determinants of Occupational Health Hazards among Roadside Automobile Mechanics in Zaria, North Western Nigeria. Borno

46. Adejumo M., Olaiya Y.V. and Sridhar M.K.C., 2017. Blood lead levels among automobile mechanics in a megacity, Lagos, Nigeria. International Journal of Health Sciences 5(2): 17-27.

47. Adeyemi H.O. Akinyemi O.O., Musa A.I. and Ibikunle B.Q. (2016). Assessment of work-space and work-method designs in Nigeria automobile service and repair industry. Nigeria Journal of technology (NIJOTECH) 35:321-328.

48. Elewon E.I (2018). Occupational hazards and risks of automobile mechanics in Port Harcourt metropolis, Rivers State, Nigeria. Int. J. of Health, Saf and Enviro 4:156-167. 
49. Ojo T.O, Onayade A.A, Akinyemi P.A, \& Adesanmi A.J. (2017). Environmental working conditions, Lung function and total serum bile acids of spray painters exposed to organic solvents in Ile-Ife, Nigeria. J Health Polu13:2-10.

50. Elms J, O'Hara R, Pickvance S. The perceptions of occupational health in primary care Soc Occupational Med. 2005;55:523-527.

51. Kalejaiye P. Occupational Health and Safety: Issues, Challenges and Compensation in Nigeria. Peak J. of Pub health and management 2013; 16-23.

52. Omokhiodon F. Occupational health in Nigeria. Occupational medicine 2009;59:201.

53. Asakitikpi A.E., 2019. Healthcare coverage and affordability in Nigeria: An alternative model to equitable healthcare delivery [Online First], IntechOpen, DOI: 10.5772/intechopen.85978. Available from: https://www.intechopen.com/onlinefirst/healthcare-coverage-and-affordability-in-nigeria-an-alternative-model-toequitable-healthcare-delive

54. Akinwale AA, Shonuga A, Olusanya O. Artisan Reaction to National Health Insurance Scheme in Lagos State, Nigeria. The J. of Glabal Healthcare Sys 2014;4:1:1-21.

55. ILO. Safety at work: A vision for sustainable prevention. Frankfurt, Germany: ILO 2014. [Cited Nov 02]. Available from: www.ilo.org/wcmsp5/groups/public/.../@ safework/.../wcms_301214.pdf. 